\title{
Philogenia nemesioi, a new damselfly from Peru (Odonata, Megapodagrionidae)
}

\author{
Angelo B. M. Machado ${ }^{1}$ \\ ${ }^{1}$ Departamento de Zoologia, Instituto de Ciências Biológicas, Universidade Federal de Minas Gerais, Caixa Postal 486, Belo Horizonte-MG, Brasil. \\ angelo@icb.ufmg.br
}

\begin{abstract}
Philogenia nemesioi, a new damselfly from Peru (Odonata, Megapodagrionidae). Philogenia nemesioi sp. nov. is described and illustrated based on one male specimen collected on forests of the eastern slope of the Peruvian Andes at $900 \mathrm{~m}$. It belongs to the cristalina group, but differs from other species of the group by the structure of the anal appendage.
\end{abstract}

KEYWORDS. Andes, cristalina group; damselflies; Insecta; taxonomy

Philogenia Selys, 1862 is a neotropical genus that occurs from Central America to Bolivia and has 35 species (Garrison et al. 2010). This number does not include Philogenia marinasilva Machado, 2010 that, according to Garrison (in litt.), is a junior synonym of P. mangosina Bick \& Bick 1988. Eight species of the genus were recorded from Peru (Tsuda 2000), as described by Selys (1862), Ris (1918), Calvert (1924), Bick \& Bick (1988), and Dunkle (1990a, 1990b). I describe herein another Peruvian species collected along a forest stream at $900 \mathrm{~m}$ on the eastern slope of the Andes.

\section{MATERIAL AND METHODS}

The holotype will be deposited at Museo de Historia Natural de la Universidad Mayor de San Marcos, Lima, Peru. All measurements are given in $\mathrm{mm}$; abdomen measurements includes appendages. Abbreviations as follows: S1-S10: abdominal segments 1 to 10 , FW: forewings, HW: hindwings.

\section{TAXONOMY}

\section{Philogenia nemesioi sp. nov.}

(Figs. 1-3)

Description. Coloration. Head: Labium black. Labrum, base of mandibles and genae yellow. Clypeus, frons, and upper part of head black with poorly defined brownish area between vertex and antennae. Back of head brown. Prothorax: pronotum laterally orangish-yellow, dorsally gray with metallic green luster. Propleuron black. Pterothorax: mesepisternum brownish orange with black middorsal carina and a faint black stripe adjacent to upper half of humeral suture. Mesepimeron black with metallic green luster and narrow orange yellow stripe adjacent to medial third of humeral suture. Metepisternum black with anterodorsal orange yellow marking. Metepimeron dominantly black with orange yel- low marking at lower quarter, hind border, and anterodorsal part of sclerite. Legs orange yellow except for dark extensor surfaces of fore legs and femora of mid- and hind legs. Wings faint orangish-yellow, more intense adjacent to veins. Venation black, pterostigma dark brown. Abdomen: S1-S2 black with dorsolateral orange yellow stripe. S3-S7 black with proximal orange yellow rings. S8-S10 black with grayishwhite dorsal band on S9-S10 and distal part of S8. Appendages black.

Structural characters. Hind prothoracic lobe rounded with a slight lateral concavity (Fig. 1). Cercus in lateral view (Fig. 2) about twice longer than S10, obliquely directed ventroposteriorly at distal two-thirds, with no mesoventral process, in dorsal view (Fig. 3) dilated at distal one-third, in ventral view with apex directed medially (Fig. 4). Paraprocts in lateral view smooth, tapering into a fine tip, with a basodorsal bulb-shaped structure (Fig. 2), in ventral view as in Fig. 4.

Measurements. Total length 59.0; FW length 33.0; HW length 34.0; pterostigma 2.7; abdomen 4.9.

Etymology. Named nemesioi in honor of my good friend Prof. André Nemésio who collected the holotype in Peru.

Type material. Holotype male: PERU - Department of San Martín, municipality of Tarapoto, 'Biodiversidad' Park ( $06^{\circ} 27^{\prime} 42^{\prime \prime} \mathrm{S} ; 7^{\circ} 17^{\prime} 19^{\prime \prime} \mathrm{W}$; ca. $900 \mathrm{~m}$ a.s.1.). 25-VII-2012. A. Nemésio leg.

\section{DISCUSSION}

Because it lacks the mesoventral process, P. nemesioi $\mathbf{s p .}$ nov. belongs to the cristalina group of Bick \& Bick (1988) together with $P$. cristalina Calvert 1909; P. ferox Racenis, 1959, P. sucra Dunkle, 1980, and P. tinalandia Bick \& Bick, 1988. It keys out to P. sucra in Heckman's key (2008) but differs from it mainly by the tapering paraproct with no tooth (not tapering and with a tooth in $P$. sucra). It differs from $P$. ferox by having paraprocts entire (bifid in $P$. ferox), from $P$. 


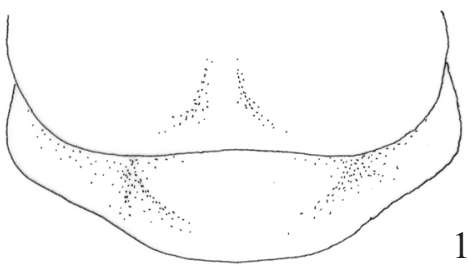

1

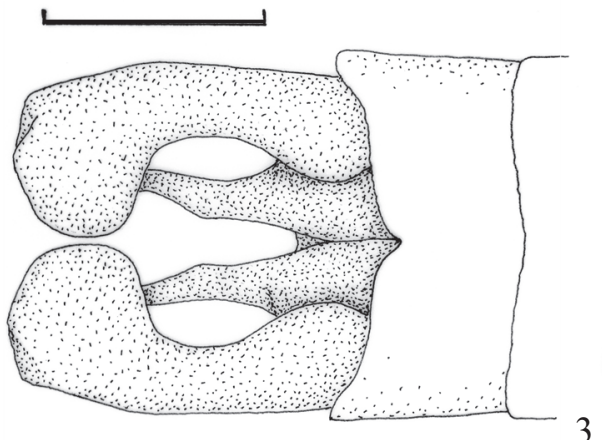

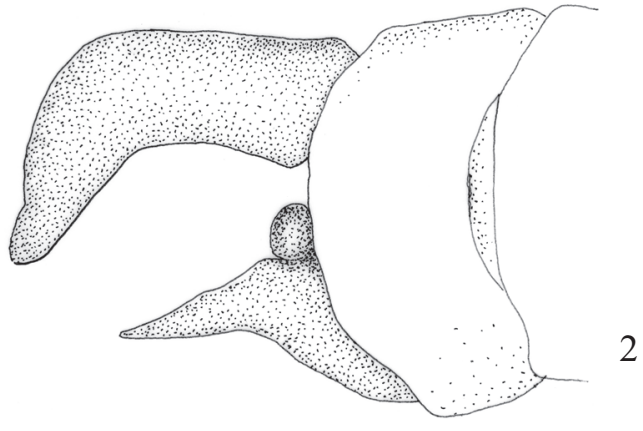

2

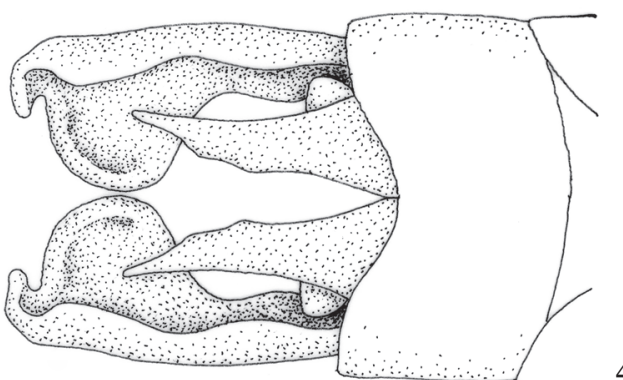

Figs. 1-4. Philogenia nemesioi sp. nov., holotype male. 1. Hind prothoracic lobe in anterodorsal view. $2-4$. Abdominal segment 10 and appendages in lateral (2), dorsal (3) and ventral (4) views. Scale bar: $1 \mathrm{~mm}$.

cristalina and $P$. tinalandia by the paraproct without tooth (with tooth in P. tinalandia and P. cristalina).

Philogenia nemesioi is part of a small collection of 23 Odonata species made by Prof. André Nemésio in the region of Tarapoto in northeastern Peru. According to Dasmaharapatra et al. (2010) this region is a well-defined 'suture zone' between two areas of endemism in the lowland rainforest: the Río Mayo/upper Río Huallaga valley systems on one side, and the lower Río Huallaga and Río Ucayali regions on the other side. This suture zone is considered by these authors to form the meeting place for separate biotas recently expanded from the putative 'Huallaga' (Western) and 'Ucayali' (Eastern) Pleistocene refuges. This very special biogeographical situation explains the enormous biodiversity of the region as revealed for birds (Davis 1986), butterflies (Dasmahapatra et al. 2010) and orchid bees (Nemésio et al. in press). The small number of Odonata species (23) obtained in a field trip aimed at collecting bees does not reflect this biodiversity and intense collecting efforts specifically directed towards odonates will most probably considerably increase this number. It is worth mentioning that although containing only 23 species, the collection of Odonata made at Tarapoto included three new species and a new genus, suggesting that the Odonata fauna of this region is poorly known prompting further collecting in the area.

\section{ACKNOWLEDGEMENTS}

I thank the biologist Myriam Morato Duarte for the drawings illustrating this paper and Prof. André Nemésio for critically reviewing this manuscript.

\section{REFERENCES}

Bick, G.H. \& Bick, J.C. 1988. A revision of males of the genus Philogenia with descriptions of five new species from South America (Zygoptera: Megapodagrionidae). Odonatologica 17: 9-32.

Calvert, P.P. 1924. The generic characters and the species of Philogenia Selys (Odonata: Agrionidae). Transactions of the American Entomological Society 50: $1-56$.

Dasmahapatra, K.K., Lamas, G., Simpson, F. and Mallet, J. 2010. The anatomy of a 'suture zone' in Amazonian butterflies: a coalescent-based test for vicariant geographic divergence and speciation. Molecular Ecology 19: 4283-4301.

Davis, T.J. 1986. Distribution and natural history of some birds from the departments of San Martín and Amazonas, northern Peru. Condor 80: $50-56$.

Dunkle, S.W. 1990a. Philogenia iquita spec. nov., a new damselfly from Peru (Zygoptera: Megapodagrionidae). Odonatologica 19: 85-89.

Dunkle, S.W. 1990b. Philogenia compressa spec. nov., a new damselfly from Peru (Zygoptera: Megapodagrionidae). Odonatologica 19: 381-384.

Garrison, R.W., von Ellenrieder, N. \& Louton, J.A. 2010. Damselfly Genera of the New World: An Illustrated and Annotated Key to the Zygoptera. Baltimore, Johns Hopkins University Press, $\mathrm{xix}+490 \mathrm{p}$.

Heckman, C.W. 2008. Encyclopedia of South American Aquatic Insects: Odonata-Zygoptera. Heidelberg, Springer, 687 p.

Nemésio, A., Seixas, D.P. \& Rasmussen, C. 2013. Sampling a biodiversity hotspot: the orchid-bee fauna (Hymenoptera: Apidae) of Tarapoto, northeastern Peru, the richest and most diverse site of the Neotropics. Brazilian Journal of Biology, in press.

Ris, F. 1918. Libellen (Odonata) aus der Region der amerikanischen Kordilleren von Costarica bis Catamarca. Archive für Naturgeschichte 82: 1-197.

Selys, E. 1862. Synopsis des Agrionines. Bulletins de l'Académie Royale des Sciences, des Lettres et des Beaux-Arts de Belgique, 2nd series, 14: 5-44.

Tsuda, S. 2000. A distributional list of world Odonata. Osaka, Author's edition, $430 \mathrm{p}$.

Received 18 December 2012; 26 August 2013

Associate Editor: Daniela M. Takiya 